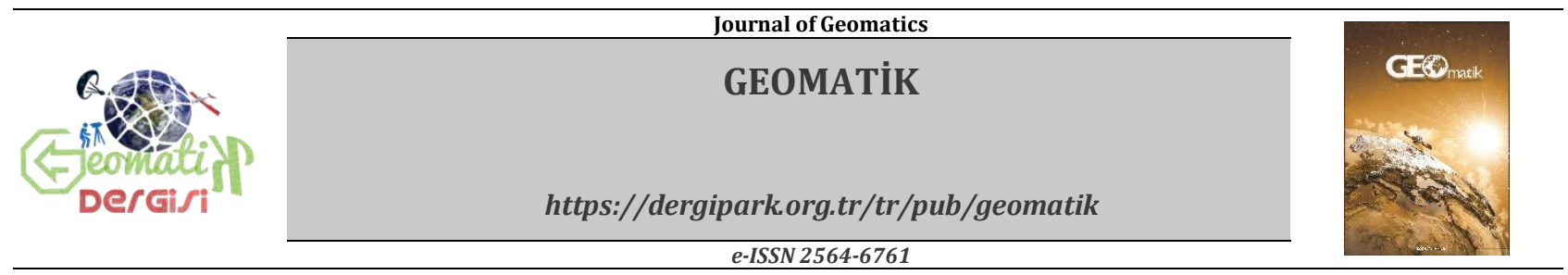

\title{
Bir imar adasındaki binaların oluşturduğu gölgelerin konum bakımından incelenmesi: Trakya Bölgesi örneği
}

\author{
Hüseyin İnce ${ }^{*}$, Nuri Erdem ${ }^{2}$ \\ ${ }^{1}$ Hitit Üniversitesi, Teknik Bilimler Meslek Yüksekokulu, Mimarlık ve Şehir Planlama Bölümü, Çorum, Türkiye \\ 2Osmaniye Korkut Ata Üniversite, Mühendislik Fakültesi, Harita Mühendisliği Bölümü, Osmaniye, Türkiye
}

\author{
Anahtar Kelimeler \\ Güneș açıları \\ Bina konumu \\ Bina gölge konumları
}

\begin{abstract}
ÖZ
Yaz mevsiminde havanın da çok sıcak olması nedeniyle insanlar, güneşin bunaltıcı etkisinden kurtulmak için gölgeli mekânları isterler. Binaların veya açık hava ortamındaki dinlenme alanlarının gölgede kalması için, yapılacak binaların veya dinlenme alanlarının, plan aşamasında, buna uygun tasarımı yapılabilir. Bir imar adasında yer alan binaların günün muhtelif saatlerinde olușturduğu gölgenin konumuna, binalar arasındaki uzaklık, binaların yüksekliği, binanın jeodezik konumu, günün saati, o saatteki güneş denklinasyon açısı, güneş azimut açısı ve güneş zenit açısı etkilidir. Günümüzde iskân alanlarında yapılacak binalar için ayrık nizam veya blok nizam uygulanmaktadır. Uygulamada, bir binanın gölge etkisiyle ilgili olarak, hazırlanmış özel yazılımlar mevcut olmakla birlikte, bir binanın gölgesinin nasıl hesaplandığı, olușan gölgenin bir imar adasında komşu binaları ne kadar etkilediği hususunda yeterli bilgiye ulaşılamadığından bu araştırmanın yapılması gerekli görülmüştür. Bu çalıșmada, Trakya bölgesinde bir imar ada cephesinin muhtelif semt açısı değerlerinde ve güneș azimut açısının muhtelif değerlerinde; bir imar adasındaki binanın, komşu bahçe sahasında, arka bahçe sahasında ve komșu parseldeki binanın cephesinde olușturduğu gölgenin konumları incelenmiştir. Çalışmanın sonunda, imar planları hazırlanırken bir imar adasında maksimum gölgelenme oluşmasını sağlamak için neler yapılması gerektiği hakkında öneriler sunulmuştur.
\end{abstract}

\section{Investigation of the shadows formed by the buildings in a reconstruction area: A case study in Trakya Region}

\section{Keywords}

Sun angles

building location

building shadow locations

\begin{abstract}
Because the weather is very hot in the summer, people want shady spaces to get rid of the sun's overwhelming effect. In order to keep the buildings or the open-air environment in the shade, the buildings or rest areas to be constructed can be designed accordingly in the planning phase. The distance between the buildings, height of buildings, geodetic location of building, the time of day, the solar equalization angle at that time, the solar azimuth angle and the solar zenith angle are effective to the position of the shadow buildings on a reconstruction island at various times of the day. Separate or block arrangement is applied for the buildings to be built in the settlement areas. In practice, although there are special software, software prepared for the shadow effect of a building, but how the shadow of a building is calculated, and this research has been deemed necessary since there is not enough information about the effect of the shadow formed on neighboring buildings. In this study, in various district angle values and sun azimuth angle of a development island facade in Trakya region; the location of the shadow building on the neighboring garden area, backyard area and on a reconstruction island and on the facade of the building in the neighboring parcel were investigated. At the end of the study, suggestions were given about what should be done in order to ensure maximum shadowing on a development island while preparing the development plans.
\end{abstract}




\section{GíRiş}

Yaz mevsiminde havanın çok sıcak olması nedeniyle güneşin bunaltıcı etkisinden kurtulmak için gölgeli mekânlar tercih edilir. Binaların veya açık hava ortamındaki dinlenme alanlarının gölgede kalması için, yapılacak binaların veya dinlenme alanlarının, plan aşamasında, buna uygun tasarımı yapılabilir. Bir imar adasında yer alan binaların günün muhtelif saatlerinde oluşturduğu gölgenin zemindeki veya bina yüzeyindeki konumuna, binalar arasındaki uzaklık, günün saati, o saatteki güneş denklinasyon açısı, güneş azimut açısı ve güneş zenit açısı etkilidir. Günümüzde iskân alanlarında yapılacak binalar için ayrık nizam veya blok nizam uygulanmaktadır.

Al-Qeeq (2008) yaptığı çalışmada binalar arasında üretilen gölge modellerin radyal ve dikdörtgen desenleri karşılaştırmıştır. Ayrıca çalışma, güneş ışığının optimal güneşlenme koşullarında yüksek kentsel dokuyu nasıl etkilediğini belirlemek amacıyla da yapılmıştır. Elde edilen sonuçların pratikte uygulanabileceğini vurgulamak ve Filistin'deki kentsel tasarımı ilerletmek için bu kalıpların uygulaması tartışılmıștır. Deneylerin yapımında kullanılan SunCast Programı, gölgeli yüzeylerin oluşumunda kullanılan ölçümlerin yüksek bir doğrulukta yapılabilmesini sağlamıştır. Önceki araştırmalar, gölge deseni üretiminde yaşanan zorluklar nedeniyle basit şekilleri inceleyebilmiştir. Son on yıllardaki teknolojik gelişmeler ve bilgisayar yazılımları daha karmaşı kentsel formların araştırılmasına imkân sağlamıştır.

Kentsel açık alanların önemli bir parçası olan sokaklar, kentsel mikro iklimlerin oluşturulmasında önemli bir role sahiptir. Sokak geometrisi ve yönlendirmesi, sokak yüzeyleri tarafından alınan güneş ışınımı miktarını ve ayrıca kentsel kanyonlardaki hava akımını etkiler. Shishegar (2013), kentsel kanyondaki sokak geometrisinin hava akımı üzerindeki etkisini vurgulamıştır. Ayrıca, cadde geometrisi ve oryantasyonunun kentsel kanyonda yaya düzeyinde hoş bir mikro iklimlendirme sağlamada kilit faktörler olduğunu kanıtlamıștır.

Peeters (2016) yaptığı çalışmada, kentsel iklim analizi için kentsel morfolojinin 3B jeoveri tabanlarını gölgelerden oluşturmak ve geometrik parametreleri analiz etmek için GIS tabanlı bir yöntem geliştirilmiştir. Bu yöntem, iç avluların boy oranı ve bunun güneş enerjisi erişimiyle olan ilişkisi üzerine odaklanmaktadır. Sonuçlar, yöntemin, daha az gelişmiş bölgelerdeki kentsel-iklim parametrelerinin analizinde 3D coğrafi veritabanlarının oluşturulmasının güvenilir ve düşük maliyetli bir süreç sunduğunu göstermektedir.

Yang ve Lin (2016) yaptığı çalışmada, yoğun nüfusa sahip kentlerde geleneksel yerleşim yerleri, bina türleri ve yerel halkın faaliyetleri nedeniyle yaşanabilecek aşırı termal stresin giderilmesi için önerilerde bulunmuşlardır. Bu çalışma kapsamında, bir yılda 12 kez termal çevre ölçümleri yapılmış ve Tayvan Tainan'da dıș mekân termal ortamını simüle etmek ve incelemek için ENVI-met modeli kullanılmıştır. Sonuçlar, modelin sıcak ve nemli bölgelere uygulandığında, ortalama radyan sıcaklık değerlerini daha doğru bir şekilde tahmin etmek için kısa dalga azaltma yönteminin kullanılabileceğini ortaya koymaktadır. Çeşitli benzetilmiş senaryolar ağaç dikmenin en etkili yöntem olduğunu göstermiştir. Tasarım prosedürünün uygulanabilirliğini ve çevrenin estetiğini geliştirmek için entegre bir dış mekân tasarım yaklaşımı önerilmiştir. Önerilen entegre prosedür, diş mekân yaşam ortamlarını iyileştirmek ve ısı stresini azaltmak için planlamacılara ve mimarlara, dış mekân tasarımında stratejiler seçme konusunda yardımcı olabilir.

Jamei ve Rajagopalan (2017) yaptıkları çalışmada, yapısal planların sıcak yaz günlerinde yaya termal konforuna etkisini araştırmıştır. Mevcut ve gelecekteki senaryolar için dış mekan insan termal ortamını değerlendirmek amacıyla yapısal planlar; artan bina yüksekliği, ağaç gölgelik kapsama alanı ve yeşil çatı ekleyerek üç aşamada modellenmiştir. Çalışma, daha derin kanyonların, daha yüksek görünüş oranlarının ve gelecekteki senaryoda daha düşük gökyüzü görünümü faktörlerinin daha düşük ortalama sıcaklıklarını arttırdığını göstermiştir.

Djekica vd. (2018) yaptıkları çalışmada, bina dıș yüzeylerinde kullanılmış kaplama malzemelerinin fiziksel özelliklerine ve yüksek yaz sıcaklıklarına maruz kaldıklarında kullanıcıların termal konforuna olan etkisine odaklanmıștır. Bir alanda kullanılan malzeme, renk, pürüzlülük ve gölgelemenin yüzeylerin ısınmasını etkilediği sonucuna varılmıştır.

Taleghani (2018), yüksek oranda yansitıcı malzemelerin kullanılması kentsel açık alanlardaki hava sıcaklığını düșürmesine rağmen, güneșin yayalar üzerindeki etkisini arttırdığını ortaya koymuştur.

Morakinyo vd. (2017) yaptığı çalışmada, ağaçlar ve binaların yayalar üzerindeki etkileri incelenmiştir. Sonuçlar, sı̆̆ kanyonların, benzer en boy oranı değerine sahip benzerlerine kıyasla daha kötü termal koşullara duyarlı olduğunu göstermektedir. Planlamacılar ve peyzaj mimarları, derin kanyonlarda yüksek gövdesi olan düşük gölgelik yoğunluğuna sahip uzun boylu ağaçları ve sığ kanyonlar ve açık alanlar için bunun tersini önermektedir.

Jamei vd. (2016) ve Sun vd. (2017) yaptığı çalışmalar, kentsel yeşil alanların arazi ısısı özelliklerine bağlı olarak peyzaj tasarımı parametrelerinin etkisiyle kentsel ısı adası etkisinin ve dolayısıyla termal konforun ılımlı olmasına yardımcı olabileceğini ortaya koymuştur. Çalışmalar, kentsel yeşil alanların yararları hakkında detaylı bilgiler sağlamakta, kent yönetimi ve kentsel peyzaj planlayıcıları için önerilerde bulunmaktadır. 
Chatzidimitriou ve Axarli (2017) yaptıkları çalışmada, Selanik'teki bir örnek olayda, farklı yönelim ve en boy oranıla sokak kanyonlarında mikroiklim verileri sağlanmıştır. Bu makale, çevredeki malzeme ve geometrik detaylara bağlı olarak, bina yükseklikleri ve kaldırım malzemelerini dikkate alarak, kentsel alan tasarımını bilgilendiren ayrıntılı mikro iklim verileri ve yaya konfor indeksleri sunmaktadır.

Tsoka (2017) yaptığı çalışmada, yüzey ve hava sıcaklıklarına ilişkin yerel termal ortamın iyileştirilmesi üzerindeki etkisinin araştırılması için değişik materyallerin kullanımı, ek bitki örtüsü ve ağaçlar kullanılmıştır. Analiz sonuçları, geleneksel bina kaplama malzemelerinin kullanılmasının yüzey sıcaklıklarında önemli bir düşüşe neden olduğunu ortaya çıkarmıştır.

Mo ve Nobuo (2018) yaptıkları çalışmanın amacl, mevcut șehir modelinin gölgeleme durumunu araştırmaktır. Araştırma Coğrafi Bilgi Sistemi (CBS), 3D modelleme programı ve istatistiksel analiz kullanılarak gerçekleştirilmiştir.

Tapias ve Soni (2016) yaptığı çalışmada, güneş erişim analizine dayanan yeni inşa edilmiş formların oluşturulması için alternatif bir yaklaşım araştırmıştır. Mevcut yerleşik formların neden olduğu gölge koşullarına dayalı rekreasyonel açık alanların oluşturulmasına ve olası kentsel gelişim alanlarının da yeni kentsel zarfların inşası için bir başlangıç noktası olmasına odaklanmaktadır.

Kent içi güneş ışığı ve gölgelenmenin kentsel yaşam kalitesine etkisinin incelenmesi, 3D şehir modellerinin gelişmesiyle daha kolay hale gelmiştir. Jaillot vd. (2017) yaptığı çalışmada, şehir modellerindeki nesnelerinin gölge etkisini algılayan bir yöntem önermiștir. Bir nesnenin gölgesi diğer uzaktaki nesneleri de etkileyebildiği için, özellikle şehir modellerinin ince geometrik ve anlamsal tanımları olabileceği düşünülerek, geniş alanları ele alan bir yöntem geliştirilmiştir.

Kentlerde yüksek bina yapımının artması, çevresindeki diğer binaları olumsuz yönde etkilemektedir. Yapılan araştırmalar, gölgenin hem insan sağlığı ve hem de üzerinde şehir planlamada olumlu veya olumsuz etkileri olduğunu göstermiștir. $\mathrm{Bu}$ nedenle "Güneş Erişimi" kent planlaması için güncel ve popüler bir konu haline gelmiştir. Rehan ve Islam (2015) yaptıkları çalışmada, bu terimin büyüklüğünü ögrenmek, bunun hakkında daha fazla bilgi edinmek ve Bangladeş gibi gelişmekte olan ülkelere tanıtmak için gölge analiziyle ilgili güncel gelişmeleri ele almıştır.

Uygulamada bir binanın gölge etkisiyle ilgili olarak, hazırlanmış özel yazılımların (URL_1; URL_2; URL_3) mevcut olduğu ancak bu özel yazılımlar kullanılarak bölgenin gölgelenme durumu ile ilgili bir araştırmanın yapılmadığı görülmüştür.

Bu çalışmada ise, Trakya bölgesinde bir imar ada cephesinin muhtelif semt açısı değerlerinde ve güneş azimut açısının muhtelif değerlerinde; bir imar adasındaki binanın komşu bahçe sahasında, arka bahçe sahasında ve yan bahçe sahasında ve komşu parseldeki binanın cephesinde oluşturduğu gölgenin konumları incelenmiştir. Elde edilen bulgular ve kanaatler belirtilmiştir. Benzer bir çalışmaya yabancı kaynaklardaki literatür araştırmalarında rastlanılmamıştır.

\section{GÜNEŞ AÇILARI}

Yapıların gün ışığından yararlanmasını sağlayacak şekilde konumlandırılmasında, güneş ışınının yeryüzünde belirlenen bir noktaya geliş doğrultusundan (güneş azimut açısından) yararlanılır. Güneş azimut açısının hesabına, çalışma bölgesinin enlemi $(\varphi)$, yllın belirli bir günü için güneşin denklinasyon açısı $(\delta)$ ile lokal öğle vaktine göre güneşin doğuş ve batış saat açıları (h) girmektedir. Bu açılara güneş açıları denir (Deriş, 1979; Kılıç ve Öztürk, 1980; İnce, 2005; Abood, 2015; Som and Pathak, 2015).

\subsection{Enlem Açısı ( $\varphi$ )}

Yeryüzündeki N noktasını dünya merkezine birleștiren doğrunun ekvator düzlemiyle yaptığı açıdır (İnce, 2005).

\subsection{Saat Açısı (h)}

Yeryüzünde dikkate alınan noktanın boylamı ile güneşi dünya merkezine bileştiren doğrunun, güneş ışınlarının belirttıği boylam arasındaki açıdır. Saat açısı, güneş boylamının göz önüne alınan yerin boylamı ile aynı olduğu "güneş öğlesi"nden itibaren hesaplanır, yerel öğle vaktinden öncesi için aradaki fark (-) işaretli, yerel öğle vaktinden sonrası için aradaki fark (+) işaretli olarak alınır. Hesaplamalarda her bir saat zaman farkı $15^{\circ}$ lik saat açısı olarak dikkate alınır (İnce, 2005).

\subsection{Denklinasyon açısı $(\delta)$}

Güneş ışınlarının ekvator düzlemiyle yaptığı açıdır (Şekil 1). Bu açı dünyanın dönme ekseninin, yörünge düzleminin normali ile yaptı̆̆ $23^{\circ} 27^{\prime} l \mathrm{lk}$ açıdan ileri gelir. Gün dönümü noktalarında (21 Haziran yaz gün dönümünde $+23^{\circ} .45,22$ Aralık kış gün dönümünde $\left.-23^{\circ}, 45\right)$ mutlak değerce maksimum olur. Denklinasyon açısı, Eş. 1'den; elde edilir (İnce, 2005). Burada n, yılın gün sayısıdır.

$\delta=23^{\circ}, 45 \sin \left(360\left(\frac{n+284}{365}\right)\right)$

\subsection{Zenit Açısı (z)}

Doğrudan güneş ışıılarının yatay düzlemin normali ile yaptığı açıdır (Şekil 1). Güneşin doğuşunda ve batışında $\mathrm{z}=90^{\circ}$ dir. Zenit açısı aşağıdaki Eş. 2'den elde edilir (Aksoy, 1975; Anderson and Mikhail, 1998; Al-Sareef et al., 2001; İnce, 2005; Farr, 2008). 
$\operatorname{cosz}=\cos \delta \cos \varphi \cosh +\sin \delta \sin \varphi$

(2)

\subsection{Güneş Yükseklik Açısı (y)}

Güneş ışınlarının yatay düzlemle yaptığı açıdır. Şekil 1'de görüldüğü gibi $z+y=90^{\circ}$ dir. Güneş yükseklik açısı y=90 - z bağıntısından elde edilir.

\subsection{Güneş Azimut Açısı ( $\beta$ )}

Güneş ışınlarının kuzeye göre saat ibresi dönüş yönünde sapmasını gösteren açıdır (Şekil 1). $\beta$, Eş. 3,
Eş. 4 ve Eş. 5'de belirtildiği şekilde elde edilir (Mcmullan, 1990; Arumı-Noe, 1996; Aksoy, 1975; Deriş, 1979; Al-Sareef et al., 2001).

Yerel öğle vaktinden önce; derece biriminde $\beta=180^{\circ}-\gamma^{\circ}$, grat biriminde $\beta=200-\gamma^{\mathrm{G}}$

Yerel öğle vaktinden sonra; derece biriminde $\beta=180^{\circ}+\gamma^{\circ}$, grat biriminde $\beta=200+\gamma^{\mathrm{G}}$

$\cos \gamma=\frac{\cos \delta \cos \varphi \cos h-\sin \delta \cos \varphi}{\cos y}$

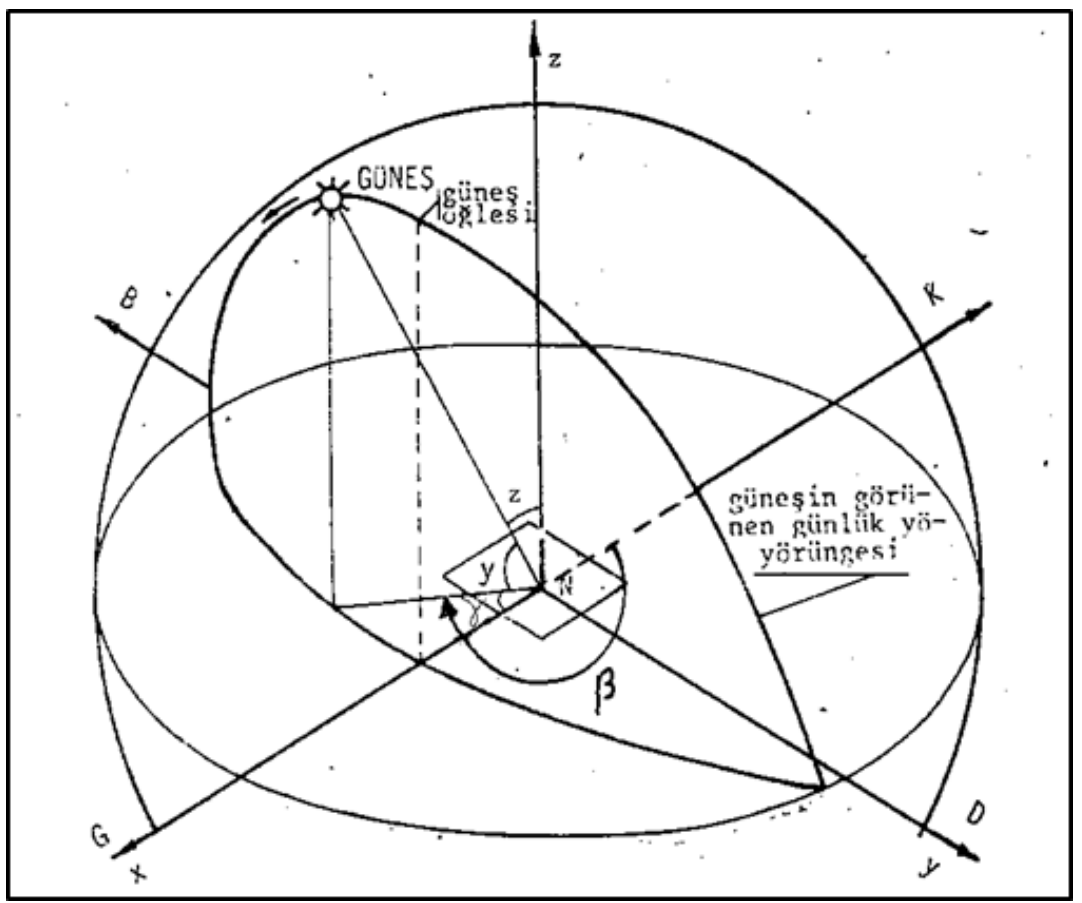

Şekil 1. Yeryüzünde bir N noktasında, güneş zenit, yükseklik ve azimut açllarının şematik görünümü

\section{TRAKYA'DA YAZ MEVSIMI IÇCiN GÜNEŞ AZIMUT ve GÜNEŞ ZENIT AÇISININ HESAPLANMASI}

Trakya Bölgesi 26024'33" ila 28011'20"

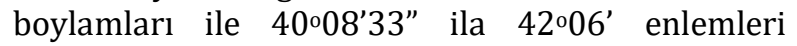
arasında yer almaktadır. Enlem olarak $40^{\circ}, 41^{\circ}$ ve $42^{\circ}$ değerleri dikkate alınmış ve bölge için ortalama enlem olarak $41^{\circ}$ değeri kabul edilmiștir.

Trakya bölgesi Edirne, Kırklareli, Tekirdağ ve Çanakkale illerinden oluşmaktadır. 21 Haziran'da belirtilen bu dört şehir için, takvimlerden elde edilen bilgilere göre güneşin doğuş ve batışına ait saatler incelendiğinde (Tablo 1); zamanlar arasında en fazla 5-6 dakikalık fark olduğu görülmüștür. Bu itibarla
Edirne için, 1 Mayıs'tan 1 Ekim'e kadar güneș doğuș ve batışıyla ilgili saat açıları kullanılmış ve elde edilen sonuçlar Tablo 2'de gösterilmiştir.

Trakya bölgesinde, güneşli bir havada bir binanın gölge konumunu belirleyebilmek için belirlenen bir zaman aralığında, güneşin doğuş ve batış açıları ile güneş denklinasyon açısına, güneş zenit açısına ve güneş azimut açısına ihtiyaç bulunmaktadır.

Güneş zenit açısının, güneş yükseklik açısının ve güneş azimut açısının hesabında; güneş denklinasyon açısı için 1 Mayıs'tan 1 Ekim'e kadar her ayın 1'i, 15'i ile 21 Haziran günlerine ait değerler Eş. 1'deki bağıntı ile hesaplanmıştır.

Tablo 1. Trakya bölgesini olușturan șehirlerdeki güneșlenme süreleri

\begin{tabular}{|l|l|l|l|l|l|l|}
\hline \multirow{2}{*}{ İller } & \multirow{2}{*}{ Enlem } & \multicolumn{5}{|c|}{ Güneş Saat Açlları } \\
\cline { 3 - 7 } & & Doğuş & Öğle & Batıș & Doğuş & Batış \\
\hline Kurklareli & $42^{\circ}$ & 5.28 & 13.23 & 21.00 & $13.23-5.28=7.55$ & $21.00-13.23=7.37$ \\
\hline Edirne & $41^{\circ}$ & 5.31 & 13.26 & 21.02 & $13.26-5.31=7.55$ & $21.02-13.26=7.36$ \\
\hline Tekirdağ & $40^{\circ}$ & 5.29 & 13.22 & 20.56 & $13.22-5.29=7.53$ & $20.56-13.22=7.34$ \\
\hline Çanakkale & $40^{\circ}$ & 5.37 & 13.26 & 20.57 & $13.26-5.37=7.49$ & $20.57-13.26=7.31$ \\
\hline
\end{tabular}


Tablo 2. Edirne'de vakitler, güneș doğuș ve batıșına ait saat açıları

\begin{tabular}{|c|c|c|c|c|c|c|}
\hline \multirow{2}{*}{ Yılın Günleri } & \multirow{2}{*}{$\mathrm{n}$} & \multicolumn{3}{|c|}{ Güneş Vakitleri } & \multicolumn{2}{c|}{ Güneş Saat Açısı } \\
\cline { 3 - 7 } & & Doğuş & Öğle & Batış & Doğuş (h) & Batış (h) \\
\hline 1 Mayıs & 121 & 6.03 & 13.21 & 20.22 & $13.21-6.03=7.18$ & $20.22-13.21=7.01$ \\
\hline 15 Mayıs & 135 & 5.46 & 13.20 & 20.34 & $13.20-5.46=7.34$ & $20.34-13.20=7.14$ \\
\hline 1 Haziran & 152 & 5.34 & 13.22 & 20.50 & $13.22-5.34=7.48$ & $20.50-13.22=7.28$ \\
\hline 21 Haziran & 172 & 5.31 & 13.26 & 21.02 & $13.26-5.31=7.55$ & $21.02-13.26=7.36$ \\
\hline 1 Temmuz & 182 & 5.35 & 13.28 & 21.02 & $13.28-5.35=7.53$ & $21.02-13.28=7.34$ \\
\hline 15 Temmuz & 196 & 5.44 & 13.30 & 20.57 & $13.30-5.44=7.46$ & $20.57-13.30=7.27$ \\
\hline 1 Ağustos & 213 & 6.00 & 13.30 & 20.42 & $13.30-6.00=7.30$ & $20.42-13.30=7.12$ \\
\hline 15 Ağustos & 227 & 6.14 & 13.28 & 20.24 & $13.28-6.14=7.14$ & $20.24-13.28=6.56$ \\
\hline 1 Eylül & 244 & 6.31 & 13.24 & 19.57 & $13.24-6.31=6.53$ & $19.57-13.24=6.33$ \\
\hline 15 Eylül & 258 & 6.46 & 13.19 & 19.33 & $13.19-6.46=6.33$ & $19.33-13.19=6.14$ \\
\hline 1 Ekim & 273 & 7.02 & 13.13 & 19.06 & $13.13-7.02=6.11$ & $19.06-13.13=5.53$ \\
\hline
\end{tabular}

Tablo 2 incelendiğinde; Edirne'de yılın belirlenen günlerinde hesaplanan güneșin doğuş ve batışına ait güneş saat açılarının 5.53 ila 7.55 saatleri arasında değiștiği görüldügünden araştırmada sınır değer olarak $\mathrm{h}= \pm 6$ değeri dikkate alınmıștır. Trakya bölgesini temsilen Tablo 1'de belirtilen zamanlar için, yukarıda belirtilen eşitliklerde hesaplanan güneş denklinasyon açlarl, $h=0$ 'dan $h= \pm 6.0$ güneş saat açllarına karşılık gelen güneş zenit ve güneş yükseklik açıları Tablo 3'de gösterilmiștir. Tablo 3'de belirtilen açılar dikkate alınarak, güneş azimut açısının hesaplamasında gerekli olan $\gamma$ açıları Tablo 4'de gösterilmiştir. Tablo 4'de $\mathrm{h}= \pm 1$ için Eş. 5 ile $\gamma$ hesabında, matematiksel bir hata $(\cos \gamma>1.0)$ oluştuğundan, $h= \pm 1$ için güneş azimut açıları, yaklaşı olarak $\mathrm{h}= \pm 2$ ya ait hesaplanmış $\gamma$ değerlerinin yarı değerleri olarak alınmıștır.

Tablo 3. Edirne'ye ait 1 Mayıs'tan 1 Ekim'e kadar güneş zenit açıları (g)

\begin{tabular}{|c|c|c|c|c|c|c|c|c|}
\hline \multirow{2}{*}{ Yılın Günü } & \multirow{2}{*}{$\begin{array}{c}\text { Denklinas. } \\
\text { Açısı } \delta^{\mathrm{o}}\end{array}$} & \multicolumn{9}{|c|}{ Saat Açları } \\
\cline { 3 - 9 } & & 0 & 1 & 2 & 3 & 4 & 5 & 6 \\
\hline 1 Mayıs & 14.9009 & 28.9990 & 32.4104 & 40.9323 & 52.0112 & 64.1851 & 76.7280 & 89.2083 \\
\hline 15 Mayıs & 18.7919 & 24.6757 & 28.4976 & 37.6572 & 49.1439 & 61.4988 & 74.0617 & 86.4436 \\
\hline 1 Haziran & 22.0396 & 21.0671 & 25.3262 & 35.0755 & 46.8848 & 59.3540 & 71.8969 & 84.1646 \\
\hline 21 Haziran & 23.4498 & 19.5002 & 23.9854 & 34.0062 & 45.9471 & 58.4534 & 70.9761 & 83.1846 \\
\hline 1 Temmuz & 23.1205 & 19.8661 & 24.2962 & 34.2528 & 46.1636 & 58.6619 & 71.1900 & 83.4129 \\
\hline 15 Temmuz & 21.5173 & 21.6474 & 25.8290 & 35.4799 & 47.2391 & 59.6925 & 72.2410 & 84.5291 \\
\hline 1 Ağustos & 17.9132 & 25.6520 & 29.3719 & 38.3810 & 49.7771 & 62.0949 & 74.6572 & 87.0650 \\
\hline 15 Ağustos & 13.7836 & 30.2404 & 35.5511 & 41.9033 & 52.8631 & 64.9777 & 77.5067 & 90.0080 \\
\hline 1 Eylül & 7.7246 & 36.9727 & 39.8325 & 47.3567 & 57.6696 & 69.4183 & 81.8175 & 94.3788 \\
\hline 15 Eylül & 2.2169 & 43.0923 & 45.6412 & 52.5272 & 62.2648 & 73.6317 & 85.8420 & 98.3842 \\
\hline 1 Ekim & -4.2155 & 50.2394 & 52.5004 & 58.7462 & 67.8374 & 78.7178 & 90.6347 & 103.071 \\
\hline
\end{tabular}


Tablo 4. Edirne için güneș azimut açılarının elde edilmesine yardımcı olan $\gamma$ açıları (g)

\begin{tabular}{|c|c|c|c|c|c|c|c|}
\hline \multirow{2}{*}{ Yılın Günleri } & \multicolumn{7}{|c|}{ GÜNEȘ AÇILARI } \\
\hline & $\mathrm{h}=0$ & $\mathrm{~h}=1$ & $\mathrm{~h}=2$ & $\mathrm{~h}=3$ & $\mathrm{~h}=4$ & $h=5$ & $\mathrm{~h}=6$ \\
\hline 1 Mayıs & $0 \mathrm{~g} .00$ & 21.9218 & 43.8435 & 68.4208 & 85.1166 & 98.6325 & 110.9501 \\
\hline 15 Mayıs & 0.00 & 23.9222 & 47.8445 & 72.3143 & 88.6488 & 101.8319 & 113.8746 \\
\hline 1 Haziran & 0.00 & 25.8927 & 51.7854 & 75.8757 & 91.7641 & 104.5896 & 116.3494 \\
\hline 22 Haziran & 0.00 & 26.8454 & 53.6909 & 77.5171 & 93.1669 & 105.8133 & 117.4348 \\
\hline 1 Temmuz & 0.00 & 26.6174 & 53.2347 & 77.1327 & 92.8366 & 105.5261 & 117.1808 \\
\hline 15 Temmuz & 0.00 & 25.5553 & 51.1106 & 75.2827 & 91.2524 & 104.1404 & 115.9491 \\
\hline 1 Ağustos & 0.00 & 23.4384 & 46.8768 & 71.4008 & 87.8326 & 101.0998 & 113.2106 \\
\hline 15 Ağustos & 0.00 & 21.4106 & 42.8212 & 67.3723 & 84.1402 & 97.7333 & 110.1173 \\
\hline 1 Eylül & 0.00 & 19.0476 & 38.0952 & 62.1665 & 79.1144 & 92.9940 & 105.6432 \\
\hline 15 Eylül & 0.00 & 17.3860 & 34.7720 & 58.0456 & 74.8968 & 88.8599 & 101.6163 \\
\hline 1 Ekim & 0.00 & 15.8845 & 31.7690 & 53.8305 & 70.3247 & 84.1975 & - \\
\hline
\end{tabular}

\section{AZIMUT AÇISI DOĞRULTUSUNDA ZENITT AÇILARINA GÖRE OLUŞAN GÖLGE BOYLARININ HESAPLANMASI}

\subsection{Güneş Azimut Açısı Doğrultusunda Komşu Binalar Arasındaki Uzaklığın Hesabı}

Güneş ışınları yeryüzündeki belirli yere, günün saatlerinde güneş azimut açısı doğrultusunda gitmektedir. Güneşli bir havada, bir imar adasında bir binanın gölgesi, komșu binalar arasındaki sahada yani komşu bahçe mesafeleri toplamındaki (KBMT) veya arka bahçe mesafeleri toplamındaki (ABMT) aralıkta, güneş azimut açısı doğrultusunda oluşur. Ülkemizde uygulanan Planlı Alanlar Tip İmar Yönetmeliği hükümlerine göre; 3, 4 ve 5 katlı yapılar için, bina yükseklikleri, komşu bahçe ve arka bahçe mesafeleri ile komşu parseller arasındaki bahçe mesafeleri toplamı Tablo5'de verilmiştir.

Tablo 5.5 kata kadar yapılar için bahçe mesafeleri ve komşu parsellerdeki binalar arasındaki yatay uzaklıklar

\begin{tabular}{|r|c|c|c|c|c|}
\hline $\begin{array}{c}\text { Kat } \\
\text { Adedi }\end{array}$ & $\begin{array}{c}\text { Bina } \\
\text { Yüksekliği } \\
(\mathrm{m})\end{array}$ & $\begin{array}{c}\text { Komşu Bahçe } \\
\text { Mesafesi (m) }\end{array}$ & $\begin{array}{c}\text { Arka Bahçe } \\
\text { Mesafesi (m) }\end{array}$ & $\begin{array}{c}\text { Komşu Bahçe } \\
\text { Mesafeleri Toplamı } \\
\text { (KBMT) }\end{array}$ & $\begin{array}{c}\text { Arka Bahçe } \\
\text { Mesafeleri Toplamı } \\
\text { (ABMT) }\end{array}$ \\
\hline 3 & 9.50 & 3.00 & 4.75 & 6.00 & 8.50 \\
\hline 4 & 12.50 & 3.00 & 6.25 & 6.00 & 12.50 \\
\hline 5 & 15.50 & 3.50 & 7.75 & 7.00 & 15.50 \\
\hline
\end{tabular}

Güneşli bir havada, bir imar adasında bir binanın $\mathrm{AB}$ cephesiyle $\varepsilon$ açısı yapacak şekilde gelen güneş ışını, $\beta$ güneş azimut açısı doğrultusunda, komşu iki bina cepheleriyle C ve D noktalarında kesişir. Şekillerde; DE: Komşu binalar arasındaki KBMT veya ABMT, DC: $\beta$ Güneş azimut açısı doğrultusunda komşu binalar arasındaki yatay uzaklıktır.

\section{$\mathrm{DC}=\mathrm{DE} / \sin \varepsilon$}

Trakya bölgesinde yapılan bir araștırmada (İnce, 2005); yapılacak bir binanın bir cephesinin semt açısı 150g -150g değerleri arasında olacak şekilde bir parsele konumlandırıldığında, gün boyunca güneş ışığından yararlandığı tespit edilmiştir (Şekil 2). Bu çalışmada; azami gölgeden yararlanma söz konusu olduğundan, binanın konumlandırılmasında bina cephesinin semtaçısının belirtilen değerlerin dişında olan $(A B)=100$ ge $(A B)=200$ g durumları dikkate alınacaktır.

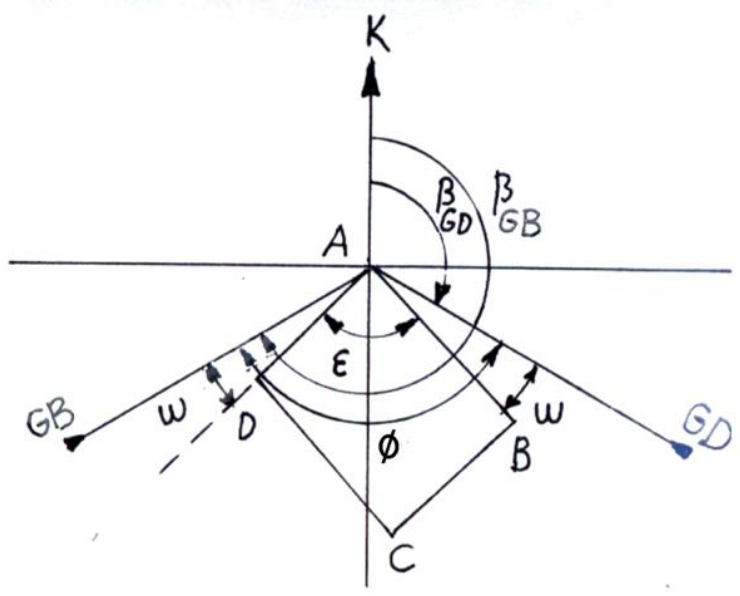

Şekil 2. Trakya bölgesinde güneș ıșığından azami yararlanacak şekilde bir binanın konumlandırılması (İnce, 2005).

Bina cephesinin semt açıları belirtilen değerlerde dikkate alınarak; $\beta$ güneș azimut açısısı doğrultusu ile bina cephesi arasındaki $\varepsilon$ açlarının elde edilişi Şekil 3, Şekil 4, Şekil 5 ve Şekil 6'da 
gösterilmiştir. Şekillerden $\varepsilon$ aşağıdaki eşitlikler ile elde edilmiştir;

1-Şekil 3 de; $(A B)=200$ g

(a) $0<\beta<100$ g için $\varepsilon=\beta$

(b) $100<\beta<200$ g için $\varepsilon=200-\beta$

2-Şekil 4 de; $(A B)=200 \mathrm{~g}$

(a) 200 g $<\beta<300$ g için $\quad \varepsilon=\beta-200$
(b) 300 g $<\beta<400$ g için
$\varepsilon=400-\beta$
3-Şekil 5; $(\mathrm{AB})=100 \mathrm{~g}$

(a) $0<\beta<100$ g için $\varepsilon=100-\beta$
(b) $100<\beta<200$ g için $\varepsilon=\beta-100$

4- Şekil 6 de; $(A B)=100$ g

(a) $200 \mathrm{~g}<\beta<300 \mathrm{~g}$ için $\varepsilon=300-\beta$

(b) $300 \mathrm{~g}<\beta<400 \mathrm{~g}$ için $\varepsilon=400-\beta$

a)

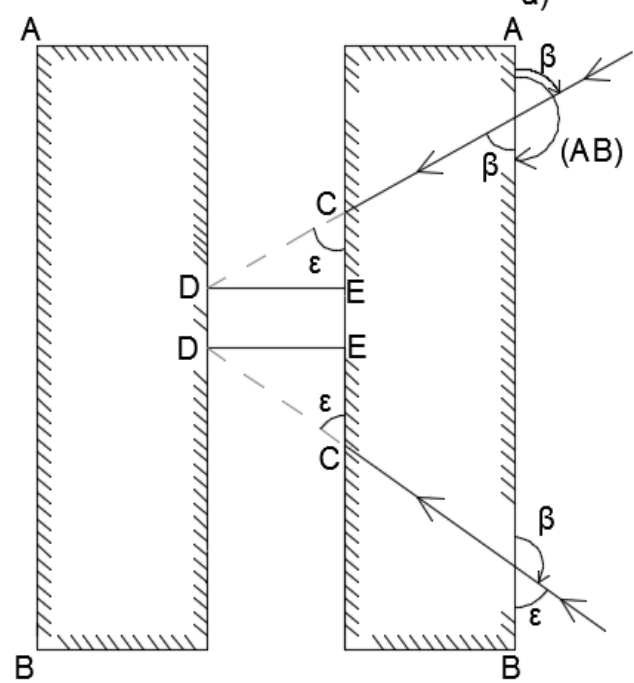

b)

Şekil 3- $(A B)=200 \mathrm{~g}, 0<\beta<100$ g ve $100<\beta<200$ g durumlarında $\varepsilon$ açısının elde edilişi

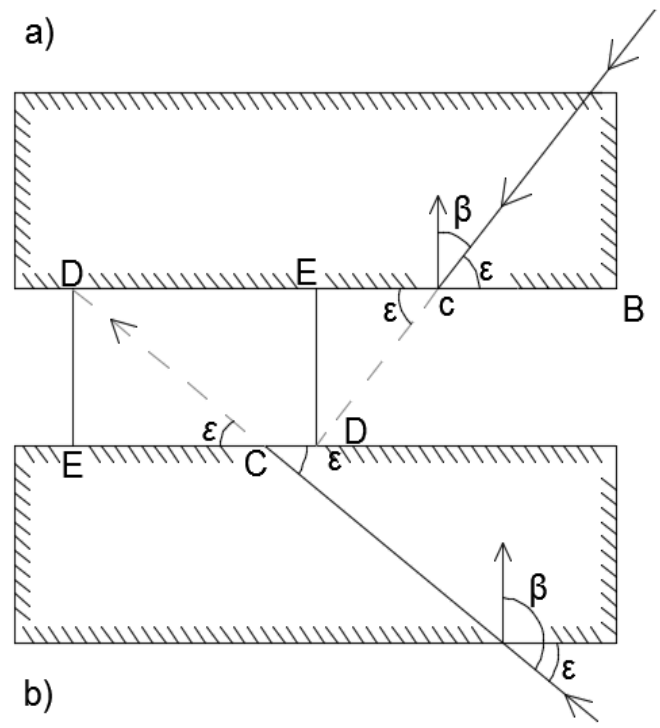

Şekil 5- $(A B)=100$ g, $0<\beta<100$ g ve $100<\beta<200$ g durumlarında $\varepsilon$ açısının elde edilişi

Bina cephesinin semt açısı $(A B)=100$ g $(\operatorname{veya}(B A)=300 \mathrm{~g})$ ve $(A B)=200 \mathrm{~g} \quad($ veya $(B A)=0 \mathrm{~g})$ kabul edilerek,Tablo 4 den elde edilen, (3) ve (4) nolu bağıntılar kullanılarak hesaplanan $\beta$ azimut

b)

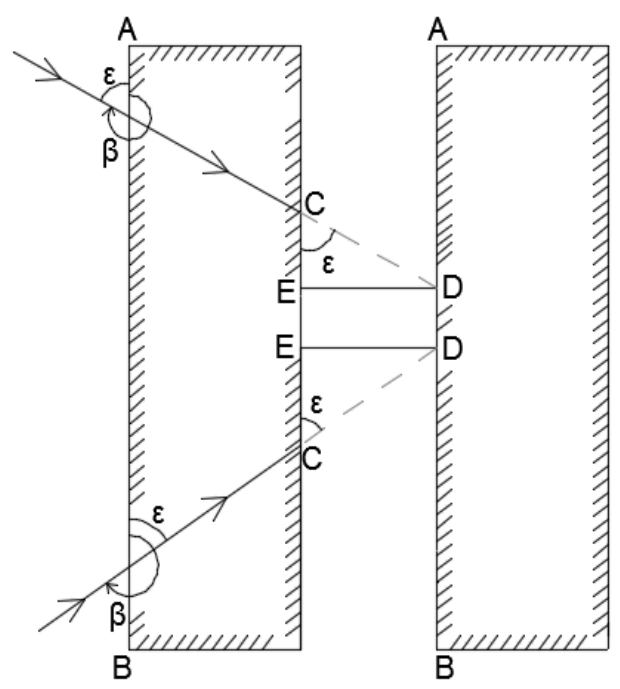

a)

Şekil 4-(AB) $=200$ g, $200<\beta<300$ g ve $300<\beta<400$ g durumlarında $\varepsilon$ açısının elde ediliși

b)

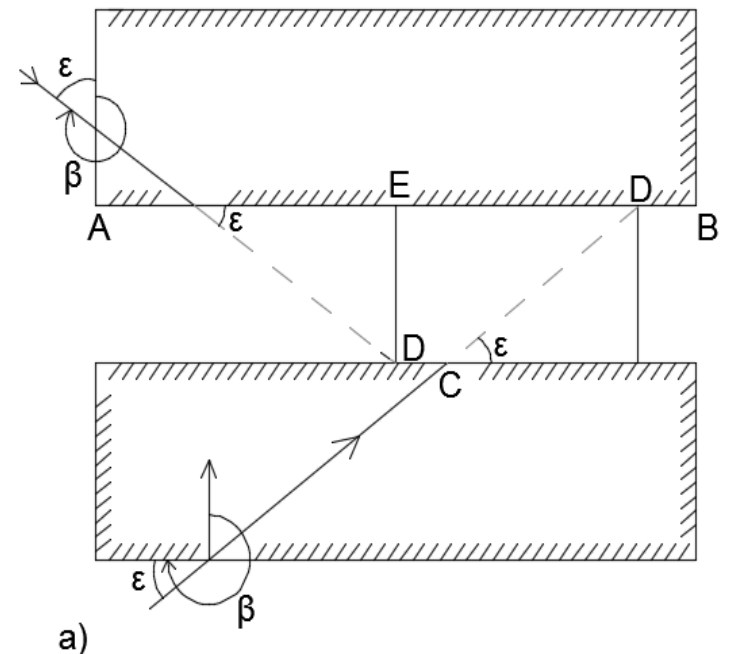

Şekil 6- $(A B)=100$ g, $200<\beta<300$ g ve $300<\beta<400$ g durumlarında $\varepsilon$ açısının elde edilişi

açıları dikkate alınarak, yukarıdaki bağıntılara göre hesaplanan $\varepsilon$ açıları Tablo 6 ve Tablo 7 de gösterilmiştir. 
Tablo 6. Edirne için $(A B)=200 \mathrm{~g}$ (veya $(B A)=0 \mathrm{~g})$ kabul edilerek hesaplanan $\varepsilon$ açllarl $(\mathrm{g})$

\begin{tabular}{|l|l|l|l|l|l|l|l|}
\hline \multirow{2}{*}{ Yllın Günleri } & GÜNEȘ AÇILARI & \multicolumn{7}{|l|}{} \\
\cline { 2 - 8 } & $\mathrm{h}=0$ & $\mathrm{~h}=1$ & $\mathrm{~h}=2$ & $\mathrm{~h}=3$ & $\mathrm{~h}=4$ & $\mathrm{~h}=5$ & $\mathrm{~h}=6$ \\
\hline 1 MAYIS & $0 \mathrm{~g} .00$ & 21.9218 & 43.8435 & 68.4208 & 85.1166 & 98.6325 & 89.0499 \\
\hline 15 MAYIS & 0.00 & 23.9222 & 47.8445 & 72.3143 & 88.6488 & 98.1681 & 86.1254 \\
\hline 1 HAZIRAN & 0.00 & 25.8927 & 51.7854 & 75.8757 & 91.7641 & 95.4104 & 83.6506 \\
\hline 22 HAZiRAN & 0.00 & 26.8454 & 53.6909 & 77.5171 & 93.1669 & 94.1867 & 82.5652 \\
\hline 1 TEMMUZ & 0.00 & 26.6174 & 53.2347 & 77.1327 & 92.8366 & 94.4739 & 82.8192 \\
\hline 15 TEMMUZ & 0.00 & 25.5553 & 51.1106 & 75.2827 & 91.2524 & 95.8596 & 84.0509 \\
\hline 1 AĞUSTOS & 0.00 & 23.4384 & 46.8768 & 71.4008 & 87.8326 & 98.9002 & 86.7894 \\
\hline 15 AĞUSTOS & 0.00 & 21.4106 & 42.8212 & 67.3723 & 84.1402 & 97.7333 & 89.8827 \\
\hline 1 EYLÜL & 0.00 & 19.0476 & 38.0952 & 62.1665 & 79.1144 & 92.9940 & 94.3568 \\
\hline 15 EYLÜL & 0.00 & 17.3860 & 34.7720 & 58.0456 & 74.8968 & 88.8599 & 98.3837 \\
\hline 1 EKIM & 0.00 & 15.8845 & 31.7690 & 53.8305 & 70.3247 & 84.1975 & - \\
\hline
\end{tabular}

Tablo 7- Edirne için $(\mathrm{AB})=100^{\mathrm{g}}$ (veya(BA)=300) kabul edilerek hesaplanan $\varepsilon$ açlları (g)

\begin{tabular}{|c|c|c|c|c|c|c|c|}
\hline \multirow[t]{2}{*}{ Yllın Günleri } & \multicolumn{7}{|c|}{ GÜNEȘ AÇILARI } \\
\hline & $\mathrm{h}=0$ & $\mathrm{~h}=1$ & $\mathrm{~h}=2$ & $\mathrm{~h}=3$ & $\mathrm{~h}=4$ & $\mathrm{~h}=5$ & $\mathrm{~h}=6$ \\
\hline 1 MAYIS & $0 \mathrm{~g} .00$ & 78.0782 & 56.1565 & 31.5792 & 14.8834 & 1.3675 & 10.9501 \\
\hline 15 MAYIS & 0.00 & 76.0778 & 52.1555 & 27.6857 & 11.3512 & 1.8319 & 13.8746 \\
\hline 1 HAZIRAN & 0.00 & 74.1073 & 48.2146 & 24.1243 & 8.2359 & 4.5896 & 16.3494 \\
\hline 22 HAZIRAN & 0.00 & 73.1546 & 46.3091 & 22.4829 & 6.8331 & 5.8133 & 17.4348 \\
\hline 1 TEMMUZ & 0.00 & 73.4447 & 46.7653 & 22.8673 & 7.1634 & 5.5261 & 17.1808 \\
\hline 15 TEMMUZ & 0.00 & 74.4447 & 48.8894 & 24.7173 & 8.7476 & 4.1404 & 15.9491 \\
\hline 1 AĞUSTOS & 0.00 & 76.5616 & 53.1232 & 28.5992 & 12.1674 & 1.0998 & 13.2106 \\
\hline 15 AĞUSTOS & 0.00 & 78.5894 & 57.1788 & 32.6277 & 15.8598 & 2.2667 & 10.1173 \\
\hline $1 \mathrm{EYLÜL}$ & 0.00 & 80.9524 & 61.9048 & 37.8335 & 20.8856 & 7.0060 & 5.6432 \\
\hline 15 EYLÜL & 0.00 & 82.6140 & 65.2280 & 41.9544 & 25.1032 & 11.1401 & 1.6163 \\
\hline 1 EKIM & 0.00 & 84.1155 & 68.2310 & 46.1695 & 29.6753 & 15.8025 & \\
\hline
\end{tabular}

Muhtelif $\varepsilon$ değerleri ve 4 ve 5 katlı yapılar için Tablo 5 'de belirtilen KBMT ve ABMT dikkate alınarak hesaplanan DC değerleri grafik olarak Şekil 6'da gösterilmiştir. Şekil 6'da $\varepsilon$ açısının küçük değerlerinde, güneş azimut açısı doğrultusunda komşu binalar arasındaki uzaklığın arttığı, $\varepsilon$ nun artan değerlerinde ise azaldığı görülmektedir.

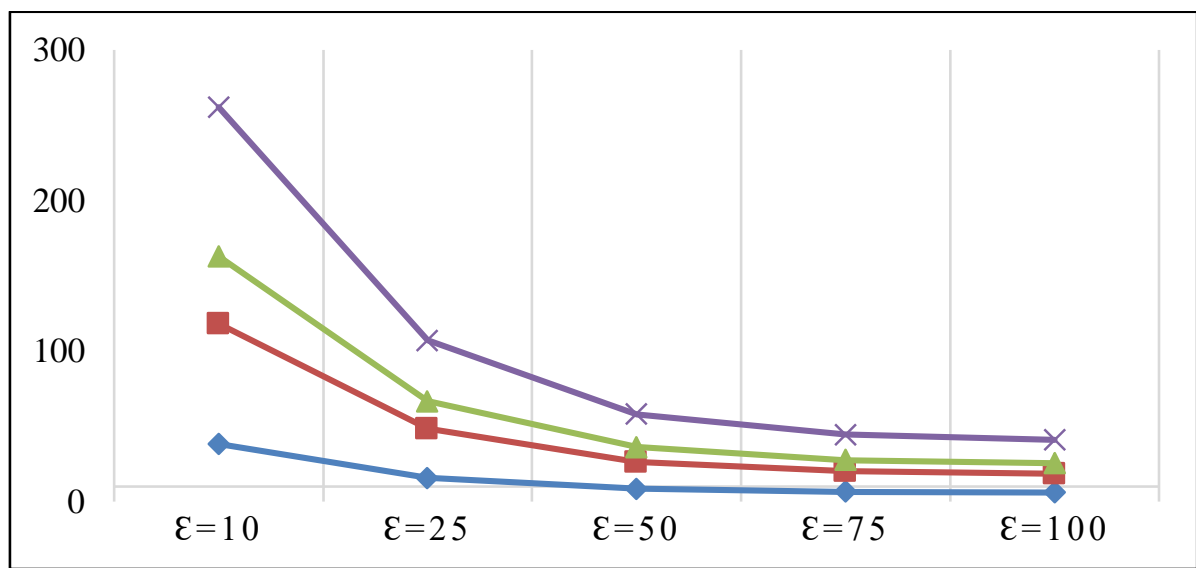

Şekil 6. Muhtelif katlı binalar için Tablo 5'deki KBMT ve ABMT değerleriyle hesaplanmış DC yatay gölge uzunluğunun muhtelif $\varepsilon$ açllarına göre değişimi

\subsection{Güneş Zenit Açılarına Göre Oluşan Bina Gölge Boylarının Hesaplanması}

Yeryüzünde güneşli bir havada, farklı zamanlarda $\mathrm{z}_{1}$ ve $\mathrm{z}_{2}$ güneş zenit açısıyla (veya $\mathrm{y}_{1}$ ve y2 yükseklik açısıyla) gelen güneş ışınlarının (Şekil 7) yerden $\mathrm{AB}$ yüsekliğindeki bir bina duvarının zemindeki BC ve FB gölge uzunlukları;

$\mathrm{BC}=\mathrm{AB} / \tan \mathrm{y}_{1}=\mathrm{AB}^{*} \tan \mathrm{z}_{1}$

$\mathrm{FB}=\mathrm{AB} / \tan \mathrm{y}_{2}=\mathrm{AB}^{*} \tan \mathrm{z}_{2}$ eşitlikleriyle elde edilir. Burada;

$\mathrm{FB}=\mathrm{FA}$ doğrultusunda $\left(\beta_{2}\right.$ güneş azimut açısı doğrultusunda) yerdeki gölgenin uzunluğu,

DB = (14) nolu eşitlik ile hesaplanan komşu binalar arasındaki yatay uzunluk,

$\mathrm{FD}=$ Oluşan gölge doğrultusunda komşu binanın tabanında kalan gölge uzunluğu,

$\mathrm{ED}=\mathrm{FB}>\mathrm{DB}$ durumunda $\mathrm{AB}$ duvarının komşu bina yüzeyinde oluşan gölgesinin, yerden yüksekliğidir. FD ve ED aşağıdaki bağıntılarla elde edilir. 
$\mathrm{FD}=\mathrm{AB}^{*} \tan \mathrm{z}_{2}-((14)$ nolu eşitlik ile elde edilen uzunluk)

(17)
(18)

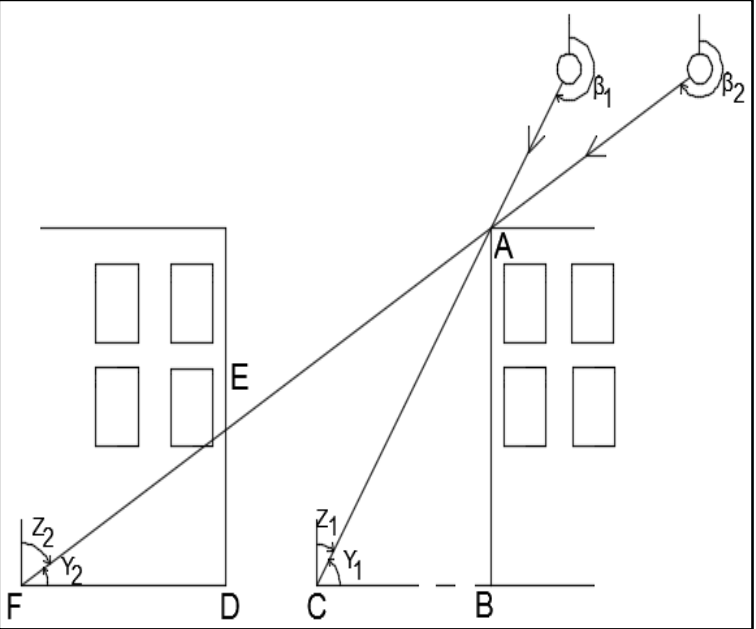

Şekil 7. Güneşli bir havada farklı zamanlarda gelen güneș ıșınlarının zeminde (komșu bahçe veya arka bahçe sahasında) ve komşu bina yüzeyinde oluşturduğu gölge uzunlukları.

Bir imar adasında bir parseldeki bina duvarının komșu parseldeki binanın yüzeyinde gölgesinin oluşması için $\mathrm{FB}>\mathrm{DB}$ olması gerekir. Eğer $\mathrm{FB}<\mathrm{DB}$ ise, bu durumda güneşe maruz kalan binanın gölgesi, komșu binalar arasındaki komșu bahçe sahasında veya arka bahçe sahasında oluşur.

$\mathrm{h}=0$ için güneş ışınları yeryüzüne dik doğrultuda geldiğinden cisimlerin gölgesi oluşmaz, bu nedenle hesaplamalarda $\mathrm{h}= \pm 1$ ila $\mathrm{h}= \pm 6$ arasındaki güneş açıları dikkate alınmıştır. Yukarıda açıklanan hususlara ve Tablo 6 ve Tablo 7 de belirtilen $\varepsilon$ açılarına göre; bina cephesini semt açısı $(A B)=100$ g ve $(A B)=200 \mathrm{~g}$ kabul edilerek, bir imar adasında ayrık yapı nizamında 5 katlı olan bir binanın, komşu bahçeler sahasında, arka bahçeler sahasında oluşan gölge uzunluğu ile komșu bina yüzeyinde oluşan gölgenin yerden yükseklikleri; Şekil 8-9-10-11'de üç boyutlu ve renkli çizimleri ile gösterilmiştir. Şekillerde komşu bahçe ve arka bahçe sahalarında oluşan gölge uzunlukları, zaman ekseninin sol tarafındaki alanda yer almaktadır ve komşu bina yüzeylerinde oluşan gölge boyları ise belirtilen alanlara bitişik konumdaki alanda yer almaktadır.

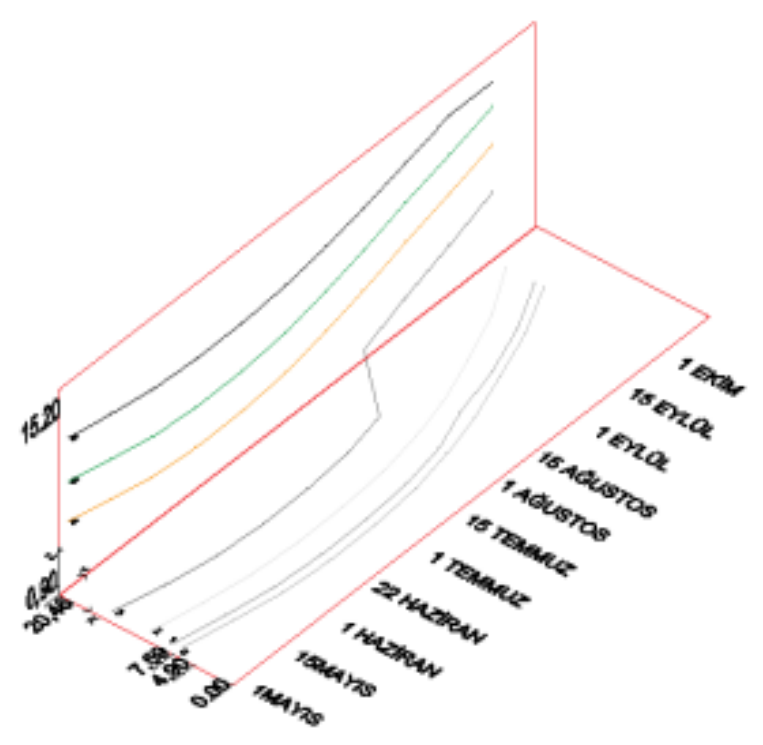

Şekil 8. $(A B)=200$ g Arka bahçeler sahasında ve komşu bina yüzeyinde oluşan gölge boyları

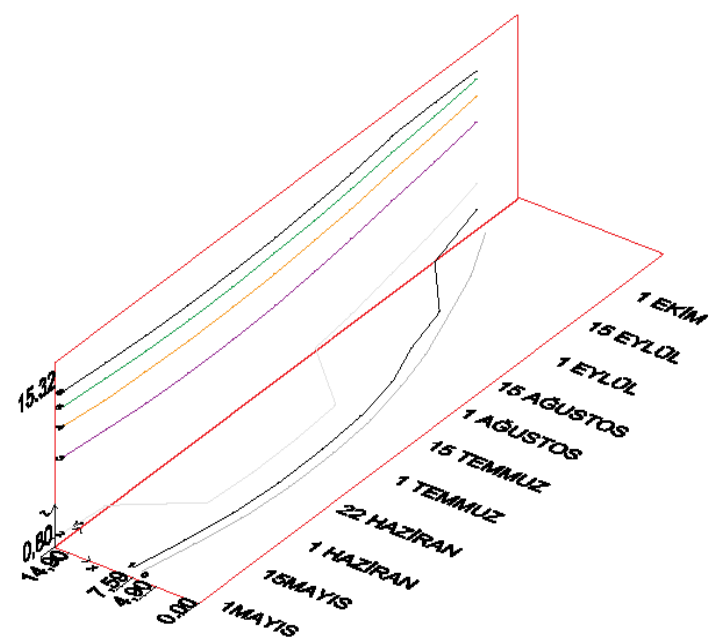

Şekil 9. $(A B)=200 \mathrm{~g}$ Komşu bahçeler sahasında ve komșu bina yüzeyinde oluşan gölge boyları

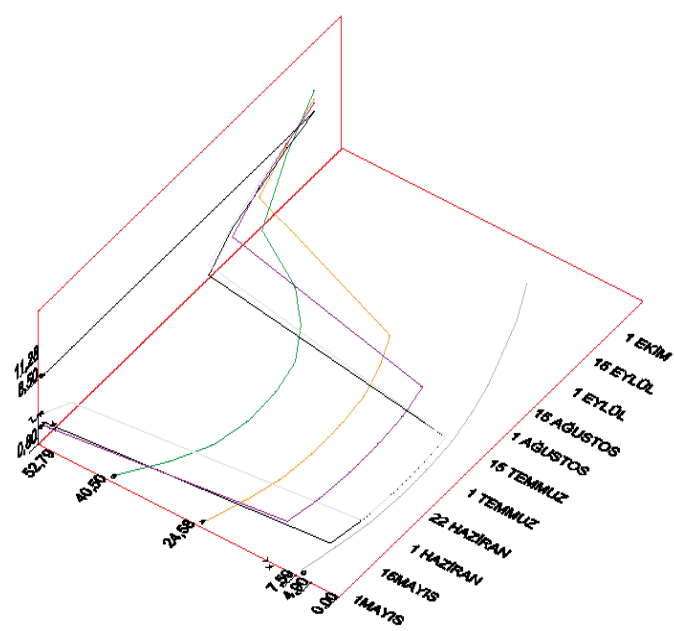

Şekil 10. $(A B)=100$ g Arka bahçeler sahasında ve komşu bina yüzeyinde oluşan gölge boyları 


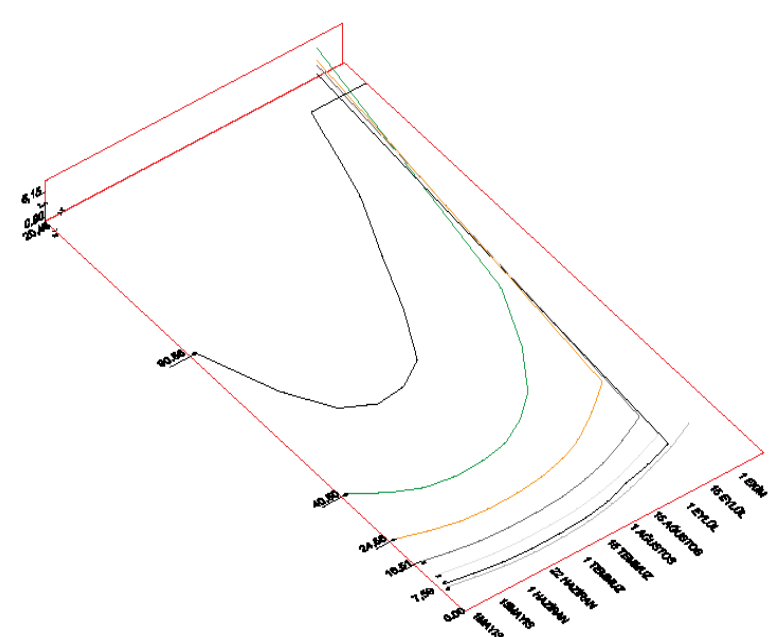

Şekil 11. $(A B)=100 \mathrm{~g}$ Komşu bahçeler sahasında ve komşu bina yüzeyinde oluşan gölge boyları

\section{UYGULAMADA BİR İMAR ADASINDA GÖLGE AYDINLIK DURUMUNUN INCELENMESI}

Bir iskân sahasında yapılașma için imar adasının cephesinin semt açıları muhtelif değerlerde olabilir. Uygulamada belirtilen bu açı değerleri yuvarlak değer olarak 0g (veya 200), 50g (veya 250g), 100g (veya 300g), 150g (veya 350g) değerlerinde veya küsuratlı değerlerde olabilir.

Buna göre; gölgelenme için yani güneşlenmemek için, 4.1 bölümünde belirtildiği şekilde bina cephesinin semt açısı olarak 200g (veya 0g) veya 100g (veya 300g) değerleri karşımıza çıkmaktadır. İmar adalarında bina cepheleri, ada cephelerine paralel konumda olduğundan, değerlendirmeyi ada cephesinin semt açısı olarak belirlemek daha doğru olacaktır.

Uygulamada SketchUP yazılımı ile, Trakya bölgesinde bir imar adasında ayrık nizamda 5 katl bir binanın örnek olarak 1 Ağustos tarihinde $\mathrm{h}=3$ güneş saatinde oluşturduğu gölgenin konumu Şekil 12 'de gösterilmiştir.

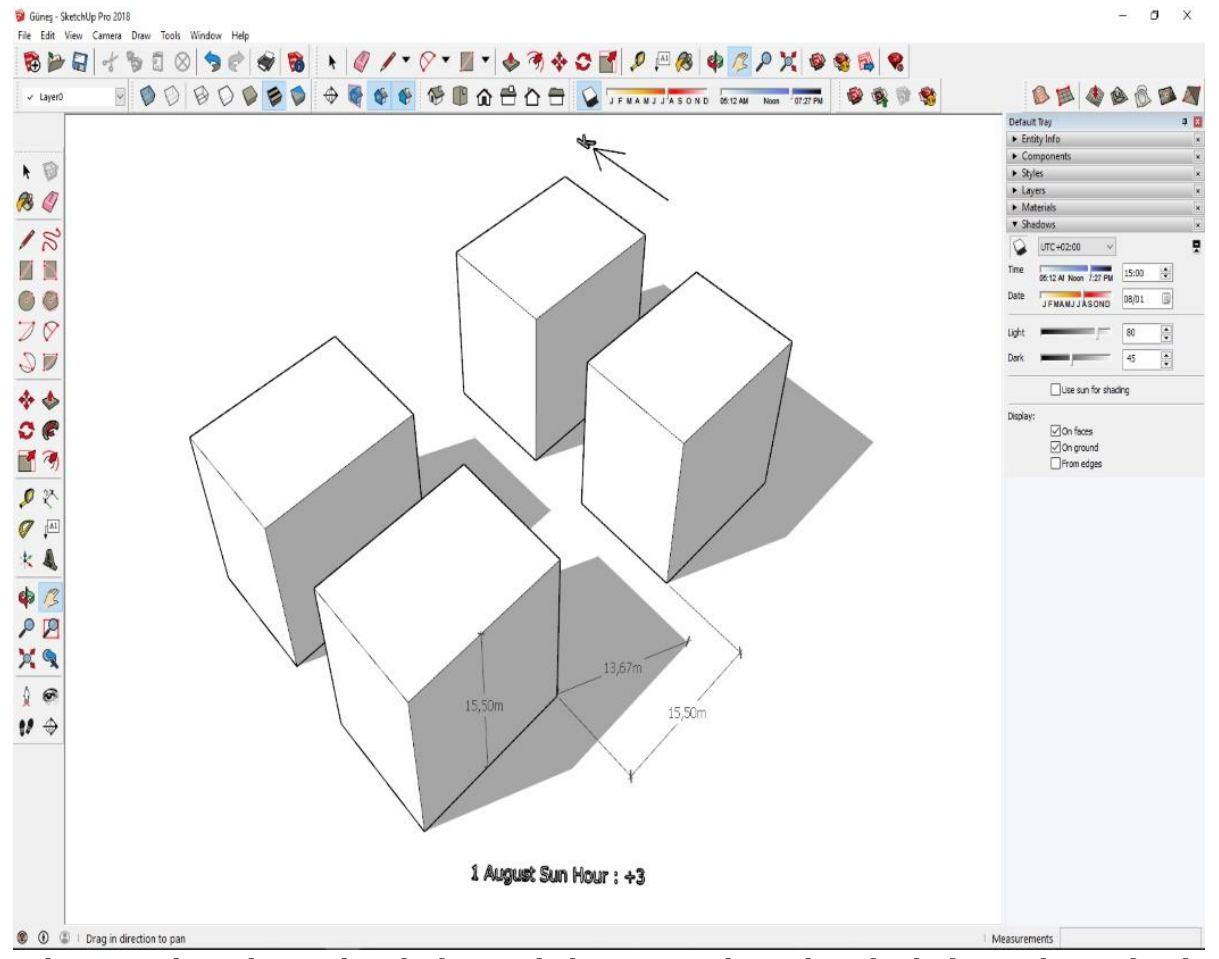

Şekil 12. SketchUP yazılımı ile, Trakya bölgesinde bir imar adasında arka bahçe sahasında oluşan gölgenin konumu ve boyutu

Bir imar adasında yapılacak bir binanın gün boyunca güneşlenmemesi için, imar adası cephesinin semt açısının $200^{g}$ ve $100^{g}$ olması halinde yani ada cephesinin kuzey-güney ve batı- doğu yönündeki konumlarında, Tablo 4'den alınan $\gamma$ açıları Eş. 3 ve
Eş. 4'de hesaplanan $\beta$ güneş azimut açları grafik olarak gösterilerek (Şekil 13, Şekil 14) inceleme yapılmıştır. 


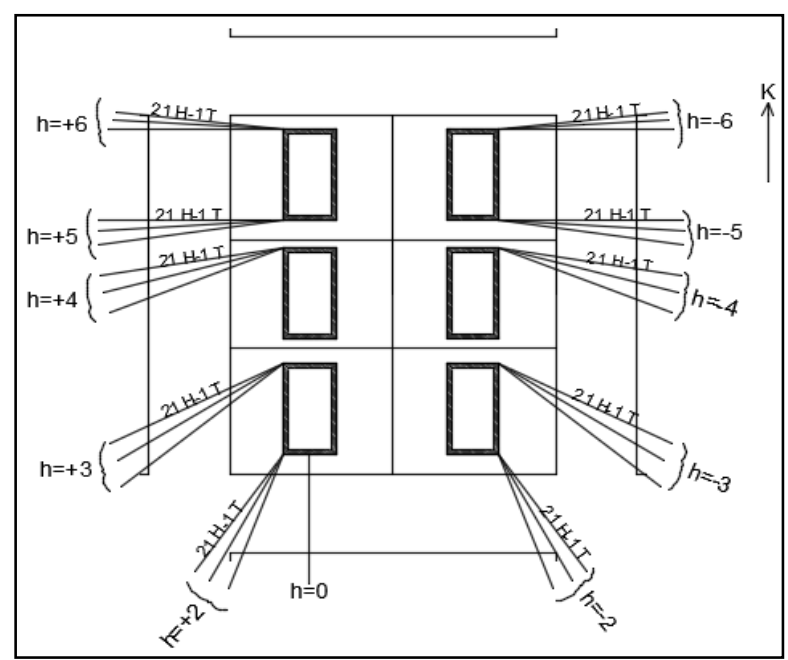

Şekil 13. İmar ada cephesi kuzey- güney doğrultusunda iken güneş azimut açısının ve güneş saat açısının muhtelif değerlerinde güneș ışınlarının binalara gölge-aydınlık etkileri

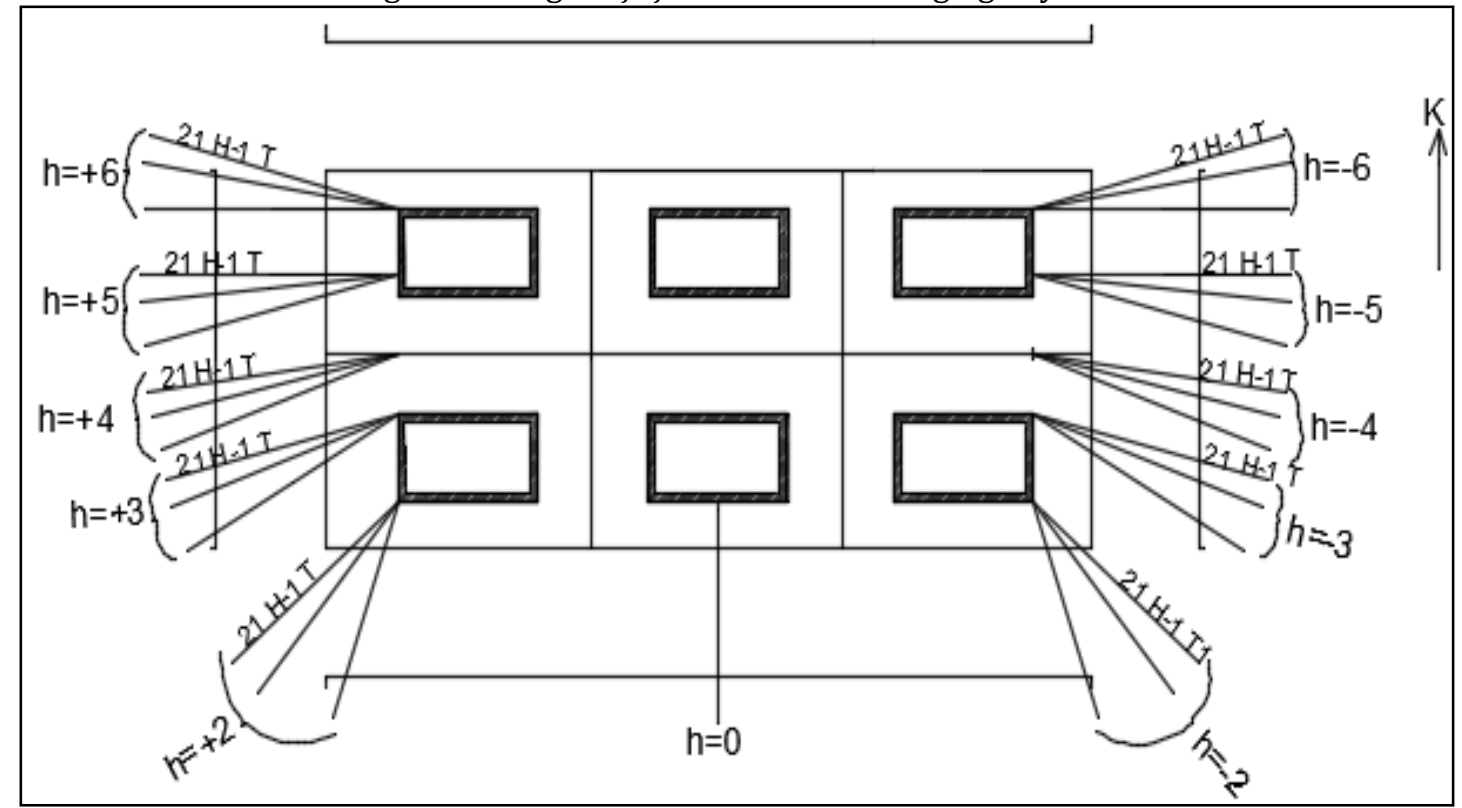

Şekil 14. İmar ada cephesi batı- doğu doğrultusunda iken güneş azimut açısının ve güneş saat açısının muhtelif değerlerinde güneş ışınlarının binalara gölge-aydınlık etkileri

Binaların ön ve arka cephelerinin doğu batı doğrultusunda konumlandırılması durumunda;

- $\mathrm{h}= \pm 6$ da sabah ve akşam saatlerinde parsellerdeki binaların kuzeye bakan ön cephelerinin yandan gelen güneș işınlarının kısmen etkisinde olduğu, binaların arka cephelerinin gölgede kaldığ

- $\mathrm{h}= \pm 3$ ila $\mathrm{h}= \pm 5$ arasında parsellerdeki binaların ön cephelerinin ve güneye bakan cephelerinin güneş ıșığına maruz kaldığı, binaların kuzeye bakan cephelerinin (adanın kuzeyinde yeralan binaların ön cephelerinin, adanın güneyinde yeralan binaların arka cephelerinin) gölgede kaldığı,

- $\mathrm{h}=0$ ila $\mathrm{h}= \pm 2$ arasında parsellerdeki binaların güneye bakan yan cephelerinin yani adanın güneyindeki binaların yan cephelerinin güneş ışınlarına maruz kaldığı, binaların kuzeye bakan arka cephelerinin gölgede kaldığı görülmüştür.
Binaların ön ve arka cephelerinin kuzey güney doğrultusunda konumlandırılması durumunda;

- $\mathrm{h}= \pm 6$ da sabah ve akşam saatlerinde parsellerdeki binaların kuzeye bakan genellikle kapalı olan yan cephelerinin yandan gelen güneş ışınlarının etkisinde olduğu, binaların arka cephelerinin ve güneye bakan yan cephelerinin gölgede kaldığgl,

- $\mathrm{h}= \pm 3$ ila $\mathrm{h}= \pm 5$ arasında parsellerdeki binaların ön cephelerinin ve güneye bakan yan cephelerinin güneş ışığına maruz kaldığı, binaların arka cephelerinin gölgede kaldığl,

- $\mathrm{h}=0$ ila $\mathrm{h}= \pm 2$ arasında parsellerdeki binaların güneye bakan cephelerinin yani adanın güneyindeki binaların yan cephelernin güneş ışınlarına maruz kaldığı, binaların kuzeye bakan diğer yan cephelerinin gölgede kaldığı görülmüștür.

Binaların ön ve arka cephelerinin kuzey- güney doğrultusunda konumlandırılmasında, binaların 
batı doğu doğrultusunda konumlandırımasına göre; ön ve arka cephelerinin daha az güneşe maruz kaldğı ve daha çok gölgede kaldıkları görülmektedir.

\section{BULGULAR}

Genel olarak, 1 Mayıs'tan 1 Ekim'e kadar oluşan gölgelerin zemindeki uzunluğunun, $h=0$ ila $h= \pm 6$ güneş saatleri arasında zamanla orantılı olarak arttığı görülmüsstür.

\section{1- Bina cephesi veya ada cephesi kuzey- güney doğrultusunda $($ yani $(A B)=200$ g veya $(B A)=0 \mathrm{~g}$ olduğunda) olduğunda}

Şekil 8 incelendiğinde; arka bahçeler sahasında güneşli bir havada:

- 15 Ağustos'tan itibaren 1 Ekim'e kadar $\mathrm{h}= \pm 3$ saatinde ve $h= \pm 4$ ila $h= \pm 6$ saaatleri arasında, sahanın tamamı gölgede kaldıktan sonra gölgenin, komşu binanın yüzeyinde oluştuğu,

- Bu oluşumun 15 Ağustos'ta $h= \pm 3$ de zeminden itibaren $0.89 \mathrm{~m}$ den $\mathrm{h}= \pm 6$ da 15 Eylül'de $15.20 \mathrm{~m}$ ye yükseldiği görülmüştür.

Şekil 9 incelendiğinde; komşu bahçe sahasında güneşli bir havada:

-1 Haziran'dan 15 Temmuz'a kadar $\mathrm{h}=0$ den $\mathrm{h}= \pm 2$ 'ye kadar sahada gölge oluştuğu,

-1Mayıs'tan 1Ekim'e kadar $\mathrm{h}= \pm 2$ ila $\mathrm{h}= \pm 6$ saatleri arasında sahanın tamamı gölgede kaldıktan sonra gölgenin, komşu binanın yüzeyinde oluștuğu,

- $\mathrm{h}= \pm 1$ ila $\mathrm{h}= \pm 2$ saatleri arasında kısmen komşu bina cephesinde gölge oluştuğu,

-komşu bina cephesinde oluşan gölgenin yerden itibaren 0.03 mden 15.32 m ye kadar yükseldiği görülmüştür.

\section{2- Bina cephesi veya ada cephesi kuzey- güney doğrultusunda $($ yani $(A B)=100 \mathrm{~g}$ veya $(B A)=300 \mathrm{~g}$ olduğunda) olduğunda}

Şekil 10 incelendiğinde; arka bahçeler sahasında güneşli bir havada:

-Genel olarak arka bahçe sahasında, kısmen 1 Ekim'de $\mathrm{h}= \pm 2$ ila $\mathrm{h}= \pm 5$ saatleri arasında, sahanın tamamı gölgede kaldıktan sonra komşu bina cephesinde gölge oluştuğu görülmüştür.

Şekil 11 incelendiğinde; komșu bahçeler sahasında: - 1 Ağustos'tan 1Ekim'e kadar $\mathrm{h}= \pm 1$ ila $\mathrm{h}= \pm 5$ saatleri arasında komşu bina yüzeyinde, diğer zamanlarda komşu bahçe sahasında gölge oluştuğu,

- $\mathrm{h}= \pm 6$ saatinde 1 Mayıstan 1 Ekim'e kadar komşu bina yüzeyinde oluşan gölgenin $8.50 \mathrm{~m}$ sabit uzunlukta kaldığı görülmüştür.

\section{TARTIŞMA}

1- Trakya bölgesinde yapılan bir araştırmada (İnce, 2005); binaların yıl boyunca güneşlenmesi için, yapılacak bir binanın cephesinin, $150^{\mathrm{g}}-250^{\mathrm{g}}$ semt açısı değerleri arasında kalması gerektiği belirtilmektedir. $\mathrm{Bu}$ tespitten hareket edilerek, Trakya bölgesinde gölgelenme konusunun araștırılmasında; olușacak gölgede, bina veya ada cephesinin konumunun etkisini tespit etmek amacıyla, iki farklı doğrultuda yani kuzey- güney doğrultusunda ve batı-doğu doğrultusunda bina konumu sabit kabul edilmiştir.

2-Belirlenen doğrultularda bina cephesinin konumu sabit kabul edildiğinde, değișken olan, gün boyunca değișen güneş azimut açısının doğrultusudur.

3- Bina cephesinin konumu sabit bir değerde alındığında, bina cephesi ile güneş ışının doğrultusu arasındaki $\varepsilon$ açısının gerçek değerlerinde elde edilmesi sağlanmıştır.

4- Bina cephesi semt açısının 200g alınması durumunda, bütün güneş saatlerinde $\varepsilon$ açısının hiç dar açı oluşturmadığı, oluşan gölgelerin bahçe sahalarında ve komşu bina cephesinde yer aldığı görülmüş̧ür.

5- Bina cephesi semt açısının 100g alınması durumunda $\mathrm{h}= \pm 5$ güneş saatinde hesaplanan $\varepsilon$ açılarında dar açılar tespit edilmiştir. $\varepsilon$ nun dar açılı olması durumunda, güneş azimut açısı doğrultusunda, bahçe sahalarına girmeyen çok uzun gölgelerin oluştuğu görülmüştür.

6- Yukarıdaki şekillerin analizinden; binaların komşu bahçe sahasında ve arka bahçe sahasında; bina veya ada cephesinin kuzey güney yönünde konumlandırılmasında, batı-doğu yönünde konumlandırımasına göre; daha az güneşe maruz kaldğı ve daha çok gölgede kaldıkları görülmektedir.

\section{SONUÇLAR}

- Trakya bölgesinde bir imar adasında ayrık yapı nizamında yer alan binaların, 1 Mayıs - 1 Ekim tarihleri arasında güneşli bir havada gölgelenme durumunun, güneş açllarının 0 ila 6 saatleri arasında, $\beta$ azimut açısına ve bina cephesinin konumuna ve dolaylı olarak $\varepsilon$ açısına bağlı olarak, genel olarak zemindeki gölge uzunluğunun arttı̆̆ görülmüştür.

- Gün boyunca azami güneş ışığından yararlanmak için imar parseli ve ada cephesinin, güneş azimut açılarının 50g ila 250g değerlerine göre konumlandırılması; gerektiği ilkelerine göre, binanın güneşlenmemesi için imar adası cephesi semt açısının 200g (veya 0g) veya $100^{g}$ (veya $300^{\circ}$ ) olması gerekmektedir.

- Binaların, bina veya ada cephesinin kuzey güney yönünde konumlandırılmasında, batıdoğu yönünde konumlandırımasına göre; daha az güneşe maruz kaldğı ve daha çok gölgede kaldıkları görülmektedir. 
- Bu sonuçtan hareketle, Trakya bölgesinde yapılacak binaların daha çok gölgede kalması için, imar düzenlemesinde, genel olarak imar adaları cephelerinin kuzey güney doğrultusunda konumlandırılması önerilir.

\section{BİLGILENDİRME}

Bu çalıșmanın genișletilmiș özeti 8-10 Kasım 2018 tarihleri arasında Harran Üniversitesi'nde (Şanlıurfa) düzenlenen "6. Uluslararası GAP Mühendislik Kongresi-(GAP 2018)" isimli etkinlikte sunulmuş ve elektronik ortamdaki etkinlik bildiri kitapçığında yayınlanmıştır.

\section{KAYNAKÇA}

Abood, A.A. (2015). A Comprehensive solar angles simulation and calculation using Matlab. International Journal of Energy and Environment (IJEE), Volume 6, Issue 4, pp. 367376.

Aksoy, A. (1975). Jeodezik astronominin temel bilgileri (küresel astronomi), M. T. Basımevi, İstanbul.

Al-Qeeq, F. (2008). Passive solar urban designshadow analysis of different urban canyons, AnNajah Univ. J. Res. (N. Sc.) Vol. 22.

Al-Sareef, F. M., Oldham, D. J. and Carter, D. J. (2001). A computer model for predicting the daylight performance of complex paralel shading systems. Building and Environment, n: 36; 60518.

Anderson, J.M. and Mikhail, E.M. (1998). Surveying theory and practice, 7th ed. Boston, MA: Mc Graw Hill.

Arumi-Noe, F. (1996). Algorithm for geometric contruction of an optimum shading. Automation in Construction, n: 5; 211-7.

Chatzidimitriou, A. and Axarli, K. (2017). Street, canyon geometry effects on microclimate and comfort; a case study in Thessaloniki, Procedia Environmental Sciences, 38, 643 - 650

Deriş, N. (1979). Güneş enerjisi sıcak su ile isıtma tekniği, Sermet Matbaası, İstanbul.

Djekica, J., Djukicb, A., Vukmirovicb, M., Djekicc, P. and Brankovic, M.D. (2018). Thermal comfort of pedestrian spaces and the influence of pavementmaterials on warming up during summer. Energy and Buildings, 159, 474-485

Erdem, N. ve İnce, H. (2016). The proposal of the building application for more benefiting from solar light, Selçuk International Scientific
Conference on Applied Sciences Conference, 2730 September, Belek- Antalya, CD Copy, 199 p., 175x250 mm, ISBN 978-605-65700-1-8.

Farr, D. (2008). Sustainable urbanism: urban design with nature, Wiley, New Jersey.

Mcmullan, R. (1990). Environmental Science in Building, Macmillan, Hong Kong.

Oduncu, E., and Esen Yüksel, S. (2018). An investigation of the effect of neighboring objects to shadow areas on real data based on the physical radiance model. Journal of the Faculty of Engineering and Architecture of Gazi University, 33:3 (2018) 887-904, https://doi.or./10.17341/gazimmfd.416393.

Oktay, D. (2004). Urban design for sustainability: a study on the turkish city. International Journal of Sustainable Development and World Ecology, 11/1, March, 24-35.

Keleş, N. S. (2016). Gölgeleme elemanlarının bina enerji harcamalarına ve kullanıcı konforuna etkisinin değerlendirilmesi: üniversite kampüsünde bir ofis binası örneği, 2. Ulusal Yapı Fiziği ve Çevre Kontrolü Kongresi, Yapı Fiziği Derneği, 04-06 Mayıs, İTÜ Mimarlık Fak, İstanbul.

Kılıç, A., ve Öztürk, A. (1980). Güneş enerjisi, İTÜ Mak. Fak., Kipaş Dağıtımcılık, İstanbul.

İnce, H. (2005). Trakya bölgesinde toplu konut alanlarında yapılacak binaların gün boyu güneș işığından yaralanması için bir tasarım önerisi, 4 . Planlı Dönemde Trakya'da Sanayileşme ve Çevre Sempozyumu, TMMOB Makine Mühendisleri Odası Bildiriler Kitabı, Sayfa 371380, 14-15 Ekim, Edirne.

İnce, H. ve Erdem, N. (2018). Gün işığından azami yararlanacak şekilde yapılacak binalar için alan tasarrufu bakımından parsel konumunun araştırılması, Mühendislik Alanında Akademik Araștırmalar, ISBN.978-605-288-390-7, www.gecekitapligi.com, s.143-161, Ankara.

Mo, K.M. and Nobuo, M. (2018). A study of tree pattern and tree species of colonial grid pattern city in tropical zone considering urban morphology using statistical analysis, International Journal of Engineering and Technology, Vol. 10, No. 5, October.

Morakinyo, T.E., Kong, L., Lau, K.K.L., Yuan, C. and Ng, E. (2017). A study on the impact of shadow-cast and tree species on in-canyon and neighborhood's thermal comfort, Building and Environment, 115, 1-17. 
Jaillot, V., Pedrinis, F., Servigne, S., Gesquière, G. (2017). A generic approach for sunlight and shadow impact computation on large city models. 25th International Conference on Computer Graphics, Visualization and Computer Vision 2017, May, Pilsen, Czech Republic. 10 p. hal- 01559175

Jamei, E. (2016). Priyadarsini Rajagopalan, Mohammadmehdi Seyedmahmoudian, Yashar Jamei, Review on the impact of urban geometry and pedestrian level greening on outdoor thermal comfort, Renewable and Sustainable Energy Reviews, 54, 1002-1017

Jamei, E. and Rajagopalan, P. (2017). Urban development and pedestrian thermal comfort in Melbourne, Solar Energy, 144, 681-698.

Peeters, A. (2016). A GIS-based method for modeling urban-climate parameters using automated recognition of shadows cast by buildings, Computers, Environment and Urban Systems, 59, 107-115.

Rehan, S.M.T.I. and Islam, K.S. (2015). Analysis Of Bulding Shadow in Urban Planning: A Review, June, Jahangirnagar University Planning Review, No 13, pp. 11-22.

Shishegar, N. (2013). Street design and urban microclimate: analyzing the effects of street geometry and orientation on airflow and solar access in urban canyons, Journal of Clean Energy Technologies, Vol. 1, No. 1, January.

Som, T. and Pathak, R. (2015). Maximum solar power generation through optimization of tilt solar angles of solar panels by heuristic technique. International Journal of Innovative Research in Electrical, Electronics, Instrumentation and Control Engineering, DOI
10.17148/IJIREEICE.2015.3409, Vol. 3, Issue 4, April.

Sun, S., Xu, X., Lao, Z., Liu, W., Li, Z., García, E.H., He, L. and Zhu, J. (2017). Evaluating the impact of urban green space and landscape design parameters on thermal comfort in hot summer by numerical simulation, Building and Environment, 123, 277-288

Taleghani, M. (2018). Outdoor thermal comfort by different heat mitigation strategies- A review, Renewable and Sustainable Energy Reviews, 81, 2011-2018.

Tapias, E. and Soni, S. (2016). Building-up urban open spaces from shadow range analyses, Towards Smarter Cities - Volume 1 - eCAADe 32, Proceedings of the 5 th International Conference on Smart Cities and Green ICT Systems April 2325 , in Rome, Italy.

Tsoka, S. (2017). Investigating the Relationship Between Urban Spaces Morphology and Local Microclimate: a study for Thessaloniki, Procedia Environmental Sciences, 38, 674-681.

Yang, S.R. and Lin, T.P. (2016). An integrated outdoor spaces design procedure to relieve heat stress in hot and humid regions. Building and Environment, 99, 149-160.

URL_1: https://www.sketchup.com/

URL_2:

https://www.autodesk.com/products/revit/newfeatures

URL_3: https://www.graphisoft.com/archicad/ 